\title{
Land Suitability for Developing Soybean Crops in Bumi Nabung and Rumbia Districts, Central Lampung
}

\author{
Sudaryono, Prihastuti and Andy Wijanarko ${ }^{1}$ \\ ${ }^{1}$ Research Institute for Legume and Tuber Root Crops Kendalpayak Road \\ Post Office Box 66 Malang \\ Correspondent address : Mobile phone: 081334727 753, e-mail: Sudaryono_Balitkabi@yahoo.com
}

Received 5 June 2009 / accepted 22 August 2010

\begin{abstract}
Bumi Nabung district consists of 6 villages with a total area of 7,810 ha which are divided into 251 ha of rain fed rice lands, 4,908 ha of dry land, 1,317 ha of lowland, 1,158 ha of yards and 176 ha of others. Rumbia district consists of 14 villages which has a total area of 22,696 ha of land consisting of 2,728 ha of yards, 17,358 ha of dry land, 326 rainfed paddy field, 839 ha of swamp land, 1,470 ha of lowland and 4,232 ha of others. Bumi Nabung and Rumbia districts have a low soil fertility potential that is reflected by the lowof soil $\mathrm{pH}, \mathrm{CEC}$, total $\mathrm{N}$, available $\mathrm{P}$, and high level of exchangeable $\mathrm{Al}$ and $\mathrm{Al}$ saturation. The results assessment based on the physical and chemical characteristics showed that Bumi Nabung district have 5 villages on suitable class S-2 (North Bumi Nabung, East Bumi Nabung, Bumi Nabung Ilir, South Bumi Nabung, and Sri Kencono) and one village New Bumi Nabung has less suitable class S-3. In the Rumbia District, there were 14 villages belonged to suitable class (S-2), namely Reno Basuki, Rekso Binangun, Teluk Dalam Ilir, Rukti Basuki, Restu Baru, Restu Buana, Bina Karya Buana, Bina Karya Putra, Bina Karya Jaya, Bina Karya Utama, Bina Karya Sakti, Joharan, Rantau Jaya Ilir and Rantau Jaya Baru. Bumi Nabung and Rumbia districts have the potential fertility and land suitability for extensification and development of soybean crops. The main technology components to support this program are the use of ameliorant (dolomite and zeolite), the application of organic fertilizers (manure and compost) and inorganic fertilizers (NPK).
\end{abstract}

Keywords: Acid soil, central Lampung, land suitability, soil fertility, soybeans

\section{INTRODUCTION}

Upland area in Indonesia is quite wide, more than 70 million ha, thus providing a huge opportunity for the extensification of crops, especially soybeans and corn (Abdurachman et al. 1998). Dry land in which agro-ecological characterized by acid Ultisol, Oxisol and an area Entisol has the largest soybean planting. The main problems of soybean cultivation in dryland Central Lampung are a low $\mathrm{pH}(<5)$, high $\mathrm{Al}$ saturation (12.0-40.1\%), hugh Fe (41.30-73.43 ppm) with $\mathrm{P}$ and $\mathrm{K}$ status are low (Taufiq et al. 2004). Soybean tolerance to $\mathrm{Al}$ saturation was $20 \%$ (Hartatik and Adiningsih 1987).

Based on the description of production constraints, the varies of commodity production are influenced by the high variability of its agroecology. This situation might have effect in a low productivity of soybean in dry land whether the soil

J Trop Soils, Vol. 16, No. 1, 2011: 85-92

ISSN 0852-257X is acid or not. To increase soybean production in the acid dry land, the soil has to obtain sufficient material consideration in determining agrocultural practices. Illustration nutrient dynamics of planting system in a certain agro-ecological sustainability provides the reference, stability of fertility, the productivity of soybean and ensure a sustainable production system.

Biophysical characterization of a target area for the development of soybean production systems in acid upland is very important to determine the synthesis of site-specific farming technology. Biophysical characterization will be the reference basis for the empowerment of land by applying the standard method of agricultural development due to prescription farming or precision farming (Shibusawa 2002). Through the description potential of a region can help planners Regional Development Plan (RPW) both at the village level (RPWD), demarcation of district and wider administrative region (Sudaryono 1994).

In the framework of the expansion of soybean acreage planted to the acid dry land, the diagnostic study and the land suitability on Bumi Nabung and 
Rumbia districts, Central Lampung Regency were needed to be done. By studying the soil physical and chemical properties in the two districts, it were expected that an input cultivation technology for optimum soybean development in the region was provided.

\section{MATERIALS AND METHODS}

\section{Site Location}

Research was conducted from May to September 2005 in the District of Bumi Nabung and Rumbia, Central Lampung Regency, Indonesia. Operational activities in the field were conducted by the method of purposive sampling. Soil sampling was done by auger at 5 sampling points in each village and then the soil was composed. Observations were made directly in the sampling locations.

\section{Soil Analysis}

These research activities can be specified as follows: (1) a physical description of the area including altitude, climate (temperature and rainfall), physiography (slope), drainage pattern, the degree of soil erosion and planting patterns (cropping pattern and crop rotation) and (2) diagnostic studies include land and soil physical and chemical characterizations including soil solum, soil texture (qualitative test), levels of soil organic matter, $\mathrm{pH}, \mathrm{CEC}$, total-C, total-N, Available-P, K, $\mathrm{S}, \mathrm{Ca}, \mathrm{Na}, \mathrm{Mg}$, and $\mathrm{Al}$.

There were 8 factors and 11 elements which were considered in assessing land suitability for soybean plants according to CSR-FAO (1983) and Landon (1984) (Table 1), i.e. temperature, water availability (dry months, rainfall), root environment (drainage, soil texture in the above layers, solum thick and soil depth), retention of nutrients (CEC,

Table 1. Criteria of land suitability for soybean plants.

\begin{tabular}{|c|c|c|c|c|}
\hline \multirow[b]{2}{*}{ Characteristics } & \multicolumn{4}{|c|}{ Level of land suitability } \\
\hline & $\begin{array}{c}\text { S1 } \\
\text { Very suitable }\end{array}$ & $\begin{array}{c}\text { S2 } \\
\text { Suitable }\end{array}$ & $\begin{array}{c}\text { S3 } \\
\text { Moderately } \\
\text { suitable } \\
\end{array}$ & $\begin{array}{c}\mathrm{N} \\
\text { Not suitable }\end{array}$ \\
\hline Score & 4 & 3 & 2 & 1 \\
\hline \multicolumn{5}{|l|}{ Temperature } \\
\hline \multirow[t]{2}{*}{ Average Temperature ${ }^{\circ} \mathrm{C}$} & $23-28$ & $29-30$ & $21-32$ & $>32$ \\
\hline & & $22-10$ & $19-18$ & $<18$ \\
\hline \multicolumn{5}{|l|}{ Water A vailability } \\
\hline Dry Month (<75 mm) & $3-7.5$ & $7.6-8.5$ & $8.6-9.5$ & $>9.5$ \\
\hline \multirow[t]{2}{*}{ Average Rainfall $\left(\mathrm{mm} \mathrm{yr}^{-1}\right)$} & $1,000-1,500$ & $1,500-2,500$ & $2,500-3,500$ & $>3,500$ \\
\hline & & $1,000-700$ & $700-500$ & $<500$ \\
\hline \multicolumn{5}{|l|}{ Root Environment } \\
\hline Drainage & Moderate-Good & Excessive & Poor & Very poor \\
\hline Texture top soil ${ }^{\mathrm{x})}$ & $\mathrm{L}, \mathrm{S}, \mathrm{CL}, \mathrm{SiL}, \mathrm{Si}, \mathrm{CL}, \mathrm{SiCL}$ & SL, SC & $\mathrm{LS}, \mathrm{SiC}, \mathrm{C}$ & G,S, Mass.C \\
\hline Soil Depth (cm) & $>50$ & $30-49$ & $15-29$ & $<15$ \\
\hline \multicolumn{5}{|l|}{ Nutrient Retention } \\
\hline CEC (me $\left.100 \mathrm{~g}^{-1}\right)$ & $>25$ & $25-15$ & $15-5$ & $<5$ \\
\hline \multirow[t]{2}{*}{$\mathrm{pH}\left(\mathrm{H}_{2} \mathrm{O}\right)$} & $6.0-7.0$ & $7.1-7.5$ & $7.6-8.5$ & $>8.5$ \\
\hline & & $5.9-5.5$ & $5.4-5.0$ & $<20$ \\
\hline \multicolumn{5}{|l|}{ Nutrient Availability } \\
\hline $\mathrm{N}$ total $(\%)$ & $>1.0-0.5$ & $0.5-0.2$ & $0.2-0.1$ & $<0.1$ \\
\hline $\mathrm{P}_{2} \mathrm{O}_{5}$ available (Bray 4) $\left(\mathrm{m} \mathrm{kg}^{-1}\right)$ & $>50$ & $50-15$ & $<15$ & $<5$ \\
\hline $\mathrm{P}_{2} \mathrm{O}_{5}$ available (Olsen 3$)\left(\mathrm{mg} \mathrm{kg}^{-1}\right)$ & $>15$ & $15-5$ & $<5$ & $<2$ \\
\hline $\mathrm{K}$ available (me $\left.100^{-1} \mathrm{~g}\right)$ & $0.8-0.4$ & $0.4-0.2$ & $0.2-0.03$ & $<0.03$ \\
\hline \multicolumn{5}{|l|}{ Salinity, mmhos $\mathrm{cm}^{-1}$} \\
\hline Sub soil & $<2.5$ & $2.5-4$ & $4-8$ & $>8$ \\
\hline Slope of Land (\%) & $0-5$ & $5-15$ & $15-20$ & $>20$ \\
\hline Al saturation $(\mathrm{Al} / \mathrm{CEC}) \%$ & $<20$ & $20-30$ & $30-40$ & $>40$ \\
\hline
\end{tabular}

Source: CSR-FAO (1983); Landon (1984)

x) Texture: $\mathrm{C}=$ Clay; $\mathrm{CL}=$ Clay loam; $\mathrm{L}=\mathrm{Loam} ; \mathrm{SCL}=$ Sandy clay loam; $\mathrm{SC}=$ Sandy clay; $\mathrm{SL}=\mathrm{Sandy}$ loam; $\mathrm{Si}=\mathrm{Silt}$; $\mathrm{SiC}=$ Silty clay; $\mathrm{SiL}=$ Silt loam $; \mathrm{S}=$ Sand $\mathrm{C}=$ Gravels; and Mass $\mathrm{C}=$ Massive clay. 
Table 2. Determination point value of land suitability for soybean crop.

\begin{tabular}{lccc}
\hline Land Suitability & Score & Percentage $(\%)$ & Point value of suitability* \\
\hline S-1 = very suitable & 4 & 100 & $3.6-4.0$ \\
S-2 = Suitable & 3 & 75 & $2.6-3.5$ \\
S-3 = moderate suitable & 2 & 50 & $1.6-2.5$ \\
N = Not suitable & 1 & 25 & $1.0-1.5$ \\
\hline Note: *percentage interval is $25 \%$, plus or minus point value of suitability is accounted by \\
$\quad$ interval $12.5 \%$.
\end{tabular}

$\mathrm{pH}$ ), nutrient availability (levels of $\mathrm{P}, \mathrm{K}$ ), salinity (below soil layer), the slope of the land and the Aluminum (Al) saturation .

Criteria land suitability for soybeans was divided by four, namely : very suitable (S1), suitable (S2), less (moderate) suitable (S3), and not suitable $(\mathrm{N})$, in that each expressed as score of $4,3,2$, and 1 (Table 1), and successively weighs $100,75,50$, and $25 \%$. Determination of point value of land suitability for soybean is shown in Table 2 .

\section{RESULTS AND DISCUSSION}

\section{Physical description of Bumi Nabung and Rumbia Districts}

Bumi Nabung and Rumbia are two of districts among 26 districts in the Central Lampung Regency. Both areas have agricultural assets with the same commodity. This situation is caused by similar conditions of topography and climate/weather. Bumi Nabung and Rumbia have altitude of about 35-50 $\mathrm{m}$ asl (above sea level). Both areas put the rice as main food commodities, followed by cassava and maize. Soybeans are still few cultivated plants in both regions, because many obstacles to ensure its production.

Bumi Nabung have 6 villages with a total area of 7,810 ha, consisted of 251 ha of rainfed rice lands, 4,908 ha of dry land (tegal), 1,317 ha lowland (lebung), 1,158 ha yards and 176 others (BPS 2004). This region has a major topography (94\%) and even a small portion (6\%) cycle with a slope of 6-10\%. Rumbia district has 14 villages covering a total area of 22,696 ha of land consisting of 2,728 ha grounds, 17,358 ha dry land, 326 rainfed paddy field, 839 ha swamp land, 1,470 he lowland and 4,232 ha of others. This region has largely flat topography and a small cycle with a slope of 6$10 \%$ (BPS 2004).

Weather conditions during the ten-year periods of year 1995-2005 in the district Bumi Nabung showed that the highest annual rainfall of $3,267 \mathrm{~mm}$ / year occurred in 1995 and the lowest of $744 \mathrm{~mm}$ $\mathrm{yr}^{-1}$ occurred in 2003. In general, this area has 6 wet months (October to April) and 6 dry months (May-September) (BPTP 2005a). During ten years periods the year 1994-2003 weather conditions in the Rumbia districts showed that the highest annual rainfall of 2,905 $\mathrm{mm} \mathrm{yr}^{-1}$ occurred in 1995 and the lowest of $743 \mathrm{~mm} /$ year occurred in 2002. In general, this area has 6 wet months (October to April) and 6 dry months (May-September) (BPTP, 2005b).

Cropping patterns in rainfed rice field in both districts were not different, the influence of weather and climate were similar. Cropping patterns in rainfed rice field included: (a) Bera-lowland ricebeans, (b) paddy rice-vegetable crops. Cropping on dry land (tegal) included: (a) Upland Rice-maizecassava, (b) Maize-Maize-cassava, (c) Maizecassava. Fertilizers recommendations for soybean in Rumbia district were $75 \mathrm{~kg}$ Urea $+150 \mathrm{~kg}$ SP-36 $+100 \mathrm{~kg} \mathrm{KCl}$ and ZA $50 \mathrm{~kg} \mathrm{ha}^{-1}$ (BPTP 2005a; 2005b).

Soil conditions in the district of Bumi Nabung and Rumbia have much in common. Most soil types $(99 \%)$ is a Red-Yellow Podsolic or Ultisol and have a surface drainage and internal drainage quite well. Thick layer of top soil was generally shallow ranging from $15-30 \mathrm{~cm}$, followed by a dense layer with a thickness varying between $20-45 \mathrm{~cm}$ and then followed by a sub soil horizon. Soil fertility conditions in general varied from a low to moderate. The soil reaction was generally acid with a soil $\mathrm{pH}$ range between 4 to 5.5 and low levels of organic material (<3\%) (BPS 2004).

Mineral composition of acid upland was dominated by clay minerals $1: 1$ type, so the use of organic fertilizer will also be a standard component in soybean cultivation in upland acid to increase soil organic matter levels, soil moisture holding capacity, soil cation exchange capacity (CEC), and some amount of soil organic colloids can chelate $\mathrm{Al}$ and $\mathrm{Fe}$ compounds. This situation will help to control acidity and toxicity of plants by $\mathrm{Al}$ and $\mathrm{Fe}$. The addition of $\mathrm{P}$ fertilizer and $\mathrm{K}$ nutrient were 
needed due to the availability of indigenous $\mathrm{P}$ and $\mathrm{K}$ on acid dry land are generally low.

\section{Soil Fertility in Bumi Nabung}

Agricultural land in the top soil $(0-20 \mathrm{~cm})$ and bottom $(20-40 \mathrm{~cm})$ of soil layer in the Bumi Nabung district is acid soil with $\mathrm{pH}$ ranged from 3.75 to 4.30 (Tabel 3). In general, $\mathrm{pH}$ of sub the soil is higher than the top soil. Difference in $\mathrm{pH}$ value between $\mathrm{pH} \mathrm{KCl}$ and $\mathrm{H}_{2} \mathrm{O}$ is very small, it means that the types of minerals in the two districts Ultisol contains no permanent charge minerals (variable charge). Elements of soil acidity can be derived from the high rate contents of $\mathrm{H}$-exchanged and $\mathrm{Al}-$ exchanged. This was also indicated by the levels of

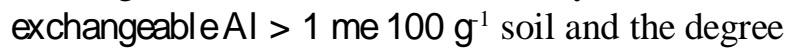
of $\mathrm{Al}$ saturation $>30 \%$. In general, C-organic content in the top soil of Bumi Nabung district was still low which in the ranged $1.56-2.3 \%$ or equal to 2.68-3.96\% give organic matter. C-organic content of the lower layer was generally lower than the top layer, which ranged $1.19-1.94 \%$ is equal to $2.05-$ $2.68 \%$ of soil organic matter. A nutrient level of phosphorus $(\mathrm{P})$ on the top soil varied between 5.58 to $26.10 \mathrm{ppm}$ and has low to moderate fertility status. Status of potassium (K) was very low, ranging from 0.07 to 0.09 me $100 \mathrm{~g}^{-1}$ soil and this value far from the low status in which below 0.2 me $100 \mathrm{~g}^{-1}$ soil. Available soil calcium $(\mathrm{Ca})$ in this district was very low ranging from 0.87 to $1.29 \mathrm{me}$ $100 \mathrm{~g}^{-1}$ soil while the low status was below 4 me $100 \mathrm{~g}^{-1}$ soil. Status of magnesium $(\mathrm{Mg})$ was low, ranging from 0.27 to 0.48 me $100 \mathrm{~g}^{-1}$ soil. Further confirmed by Truog (1973) and Landon (1984) that the soil with a $\mathrm{pH}<4.5$ has low nutrients availability of $\mathrm{P}, \mathrm{Ca}, \mathrm{Mg}, \mathrm{Mn}, \mathrm{Cu}$ and $\mathrm{Zn}$. The soil chemical characteristics in Bumi Nabung districts are shown in Table 3.

\section{Soil Fertility in Rumbia District}

Table 4 showes that agricultural soil in the top soil layer $(0-20 \mathrm{~cm})$ in the Rumbia districts had an acid soil $\mathrm{pH}$, ranging from 3.90 to 4.40 . Levels of soil C-organic in top soil layers ranged from 1.19 to $2.58 \%$ or equal to 2.05 to $4.44 \%$ of soil organic matter. C-organic content of the soil layer below $(20-40 \mathrm{~cm})$ was generally lower than the top layer, which ranged $1.19-1.94 \%$ or equal to $2.05-2.68 \%$, of soil organic matter. There were three villages (25\% of locations) which had enough level of soil organic matter that were Reno Basuki, Restu Baru and Sri Kencono villages while other $75 \%$ villages had low level of organic carbon. Soil total $\mathrm{N}$ levels in the 12 villages were very low $(<0.1 \%)$. Total $\mathrm{N}$ levels in top soil was relatively high compared to the sub soil. Nitrogen fertilizer could not be abandoned or reduced to obtain plant growth performance and optimal yields. Nutrient levels of $\mathrm{P}$ in the top soil at Rumbia districts were ranging from a low to very high. Nutrient levels of $P$ in top soil were generally higher than that in the sub soil. There were two villages namely Bina Karya Putra and Bina Karya Jaya had low P nutrient levels $(<12$ ppm P Bray I). Levels of $S$ in the soil in the two districts of Bumi Nabung and Rumbia were generally quite high (>20 ppm), and some had very high > $100 \mathrm{ppm}$. This gave a good indication of the $\mathrm{S}$ aspects in soil fertility.

Tabel 3. Soil chemical properties of Bumi Nabung district, Cemter Lampung Regency.

\begin{tabular}{|c|c|c|c|c|c|c|c|c|c|c|c|c|c|c|}
\hline \multirow{2}{*}{ No } & \multicolumn{2}{|c|}{$\mathrm{pH}$} & Org-C & Tot-N & P-Bray I & $\mathrm{SO}_{4}$ & $\mathrm{~K}$ & $\mathrm{Na}$ & $\mathrm{Ca}$ & $\mathrm{Mg}$ & $\mathrm{CEC}$ & Al-ex & H-ex & \multirow{2}{*}{$\begin{array}{c}\text { Al-sat } \\
\%\end{array}$} \\
\hline & $\mathrm{H}_{2} \mathrm{O}$ & $\mathrm{KCl}$ & \multicolumn{2}{|c|}{....... \% } & \multicolumn{2}{|c|}{$\ldots \ldots \mathrm{ppm} \ldots \ldots$} & \multicolumn{7}{|c|}{ me $100 \mathrm{~g}^{-1}$} & \\
\hline 1 & 4.20 & 4.00 & 1.56 & 0.06 & 5.58 & 22.5 & 0.09 & 0.130 & 1.09 & 0.43 & 11.60 & 1.03 & 0.23 & 34.33 \\
\hline 2 & 4.20 & 4.00 & 1.19 & 0.05 & 2.91 & 26.3 & 0.11 & 0.130 & 1.05 & 0.42 & 21.60 & 1.14 & 0.40 & 35.08 \\
\hline 3 & 4.30 & 4.05 & 1.56 & 0.05 & 26.10 & 18.1 & 0.08 & 0.130 & 0.87 & 0.41 & 8.73 & 0.91 & 0.34 & 33.21 \\
\hline 4 & 4.15 & 3.90 & 1.19 & 0.04 & 9.74 & 18.4 & 0.07 & 0.150 & 0.99 & 0.42 & 11.60 & 1.03 & 0.23 & 35.64 \\
\hline 5 & 3.75 & 3.80 & 1.66 & 0.09 & 6.73 & 276.0 & 0.08 & 0.110 & 0.49 & 0.27 & 21.60 & 2.85 & 0.86 & 61.16 \\
\hline 6 & 3.85 & 3.85 & 1.61 & 0.06 & 5.91 & 291.0 & 0.09 & 0.130 & 0.63 & 0.31 & 11.60 & 3.19 & 0.03 & 72.83 \\
\hline 7 & 4.30 & 4.00 & 1.66 & 0.03 & 21.10 & 20.4 & 0.07 & 0.130 & 1.01 & 0.44 & 18.50 & 0.91 & 0.24 & 32.50 \\
\hline 8 & 4.20 & 4.00 & 1.94 & 0.05 & 7.99 & 28.9 & 0.06 & 0.110 & 0.81 & 0.36 & 21.10 & 1.14 & 0.30 & 41.01 \\
\hline 9 & 4.20 & 4.05 & 2.30 & 0.04 & 12.80 & 22.9 & 0.08 & 0.170 & 1.29 & 0.48 & 21.10 & 0.68 & 0.47 & 21.45 \\
\hline 10 & 4.25 & 4.00 & 1.56 & 0.06 & 3.24 & 19.5 & 0.09 & 0.130 & 1.06 & 0.46 & 21.10 & 1.14 & 0.21 & 36.89 \\
\hline 11 & 4.30 & 4.00 & 1.76 & 0.04 & 20.10 & 21.4 & 0.09 & 0.120 & 1.11 & 0.42 & 19.50 & 0.95 & 0.26 & 47.50 \\
\hline 12 & 4.25 & 4.00 & 1.84 & 0.06 & 8.99 & 27.9 & 0.07 & 0.100 & 0.91 & 0.46 & 20.10 & 1.12 & 0.32 & 60.21 \\
\hline
\end{tabular}

Note: Singular number = top soil $(0-20 \mathrm{~cm})$; Plenary number $=$ sub soil $(20-40 \mathrm{~cm})$; Al-ex = Al exchangeable; $\mathrm{H}-$ ex = H exchangeable, Al-sat = Al saturation; Site No. 1-2 = Bumi Nabung Utara; 3-4 = Bumi Nabung Ilir; 56=Bumi Nabung Baru; 7-8=Bumi Nabung Timur; 9-10=Sri Kencono 11-12= Bumi Nabung Selatan. 
Table 4. Soil chemical properties in Rumbia District, Central Lampung Regency.

\begin{tabular}{|c|c|c|c|c|c|c|c|c|c|c|c|c|c|c|}
\hline \multirow{2}{*}{ No } & \multicolumn{2}{|c|}{$\mathrm{pH}$} & Org-C & Tot-N & P-Bray I & $\mathrm{SO}_{4}$ & K & $\mathrm{Na}$ & $\mathrm{Ca}$ & $\mathrm{Mg}$ & CEC & Al-ex & H-ex & \multirow{2}{*}{$\begin{array}{c}\text { Al-sat } \\
\%\end{array}$} \\
\hline & $\mathrm{H}_{2} \mathrm{O}$ & $\mathrm{Ka}$ & \multicolumn{2}{|c|}{$\% \ldots \ldots \ldots$} & \multicolumn{2}{|c|}{.......ppm. } & \multicolumn{7}{|c|}{ ….................. me $100 \mathrm{~g}^{-1}$} & \\
\hline 1 & 3.90 & 3.90 & 1.53 & 0.05 & 36.80 & 147.0 & 0.05 & 0.068 & 0.78 & 0.31 & 14.50 & 1.60 & 0.43 & 49.41 \\
\hline 2 & 4.10 & 3.85 & 0.72 & 0.03 & 1.47 & 297.0 & 0.06 & 0.069 & 0.85 & 0.35 & 17.50 & 2.17 & 0.43 & 55.23 \\
\hline 3 & 4.40 & 4.05 & 1.48 & 0.06 & 55.50 & 37.0 & 0.05 & 0.070 & 0.99 & 0.37 & 11.60 & 1.14 & 0.02 & 43.18 \\
\hline 4 & 4.15 & 4.05 & 0.78 & 0.03 & 2.82 & 309.0 & 0.03 & 0.047 & 0.66 & 0.24 & 11.60 & 1.14 & 0.50 & 43.56 \\
\hline 5 & 3.95 & 3.90 & 2.28 & 0.04 & 43.40 & 41.4 & 0.07 & 0.060 & 0.83 & 0.33 & 14.50 & 1.03 & 0.23 & 40.39 \\
\hline 6 & 4.40 & 4.10 & 1.15 & 0.03 & 1.61 & 246.0 & 0.05 & 0.090 & 0.52 & 0.25 & 14.50 & 1.26 & 0.38 & 49.41 \\
\hline 7 & 4.30 & 4.00 & 2.58 & 0.06 & 263.00 & 30.6 & 0.19 & 0.190 & 2.50 & 0.56 & 23.80 & 0.11 & 0.27 & 2.88 \\
\hline 8 & 4.25 & 4.15 & 1.30 & 0.04 & 3.92 & 60.3 & 0.09 & 0.130 & 1.03 & 0.40 & 29.10 & 0.91 & 0.15 & 33.58 \\
\hline 9 & 4.30 & 4.10 & 1.51 & 0.03 & 97.50 & 22.0 & 0.08 & 0.090 & 1.20 & 0.37 & 26.40 & 1.14 & 0.30 & 35.85 \\
\hline 10 & 4.45 & 3.90 & 1.79 & 0.03 & 6.91 & 192.0 & 0.08 & 0.070 & 0.81 & 0.35 & 21.10 & 0.68 & 0.28 & 29.96 \\
\hline 11 & 4.20 & 3.85 & 1.19 & 0.06 & 4.25 & 17.2 & 0.06 & 0.130 & 0.92 & 0.47 & 21.60 & 1.26 & 0.19 & 41.58 \\
\hline 12 & 4.40 & 4.00 & 1.38 & 0.05 & 1.34 & 172.0 & 0.07 & 0.110 & 1.24 & 0.50 & 15.80 & 0.68 & 0.38 & 22.82 \\
\hline 13 & 4.20 & 3.90 & 1.30 & 0.05 & 9.34 & 19.9 & 0.10 & 0.110 & 1.07 & 0.50 & 18.50 & 1.26 & 0.29 & 37.84 \\
\hline 14 & 4.40 & 3.90 & 1.62 & 0.05 & 1.38 & 10.7 & 0.05 & 0.110 & 1.54 & 0.51 & 23.80 & 0.80 & 0.17 & 25.16 \\
\hline
\end{tabular}

Note: Singular number $=$ top soil $(0-20 \mathrm{~cm})$; Plenary number $=$ sub soil $(20-40 \mathrm{~cm})$; Al-ex= Al-exchangeable; H-ex $=\mathrm{H}-$ exchangeable, Al-sat $=$ Al-saturation. Site No. 1-2 = Rekso Binangun; 3-4 = Rukti Basuki; 5-6 = RenoBasuki; 7-8 = Restu Baru; 9-10 = Restu Buana; 11-12 = Bina Karya Putra; 13-14 = Bina Karya Jaya.

\section{Potency of Soybean Development in Bumi Nabung and Rumbia}

Soybeans require specific growing of environmental conditions viz.climate, water availability and soil conditions. Criteria for land suitability for soybeans farming were divided by four, namely: very suitable (S1), suitable (S2), less suitable (S3) and not suitable (N) as presented in Table 1. This important measurement was known as a guide in the planning, implementation and development of soybean cultivation technology. Basic technological components were determined by agro-ecological characteristics.

Theoretically soybeans were grown in the following conditions (1) grows at an altitude of 0$1,500 \mathrm{~m}$ asl (above sea level) and optimum at about $650 \mathrm{~m}$ asl, (2) optimum temperature $29.4^{\circ} \mathrm{C}$, (3) shade tolerance $<40 \%$, (4) able to adapt to a broad climate; optimum climate type C1-2, D1-3, and E1$2,(5)$ cropping day light of soybean was short $(<12$ hours per day), (6) water consumption was 64-75 cm every cropping season or equal to $200-300 \mathrm{~mm}$ rainfall every growing season, (7) adapted to the soil but the vast and fertile soil, the optimum $\mathrm{pH}$ 6.2-7.0, Al saturation <20\% and (8) for every weight of soybean seed, the nutrient transport was more or less by $66 \mathrm{~kg} \mathrm{~N}, 15.5 \mathrm{~kg} \mathrm{P}, 39.7 \mathrm{~kg}$ of K, $7.5 \mathrm{~kg}$ of $\mathrm{Mg}$ and $7.0 \mathrm{~kg}$ of S (Baharsjah et al. 1985; Halliday and Trenkel 1992; Hartatik and Adiningsih 1987; Widjaja-Adhi 1985).
Tables 5 and 6 reported the land suitability for soybean plants. According to dignity, conformity assessment fields criteria of soybean as shown in Table 1 and 2 it can be argued that from 6 villages in the Bumi Nabung district can be classified into two fitness classes for soybeans, according to the class (S-2) the village consisted of 5 villages which were North Bumi Nabung, East Bumi Nabung, Bumi Nabung Ilir, South Bumi Nabung, and Sri Kencono; and a village of New Bumi Nabung had less dignity appropriate class (S-3). Rumbia district had 14 villages which all had a dignity appropriate class (S-2), which were Reno Basuki, Rekso Member, Teluk Dalam Ilir; Rukti Basuki, Restu Baru, Restu Buana, Buana Bina Karya, Bina Putra Karya, Bina Karya Jaya, Bina Karya Utama, Bina Karya Sakti, Joharan, Rantau Jaya Ilir and Rantau Jaya Baru.

There are physical characteristics that can not be or very difficult to manipulate, ie temperature and rainfall. Soil physical and chemical characteristics were likely to be improved. Thus, the possibility to increase the dignity of the land suitability class of the S-3 (not appropriate) to S-2 (match) and even a S-1 (very appropriate) in the Bumi Nabung and Rumbia district, Central Lampung Regency were very large. Development of soybeans in acid dry land can not escape from the soil acidity constraints resulting from aluminum (Al) and iron $(\mathrm{Fe})$ compounds. Thus, technical measurement of the soil amelioration will be part 


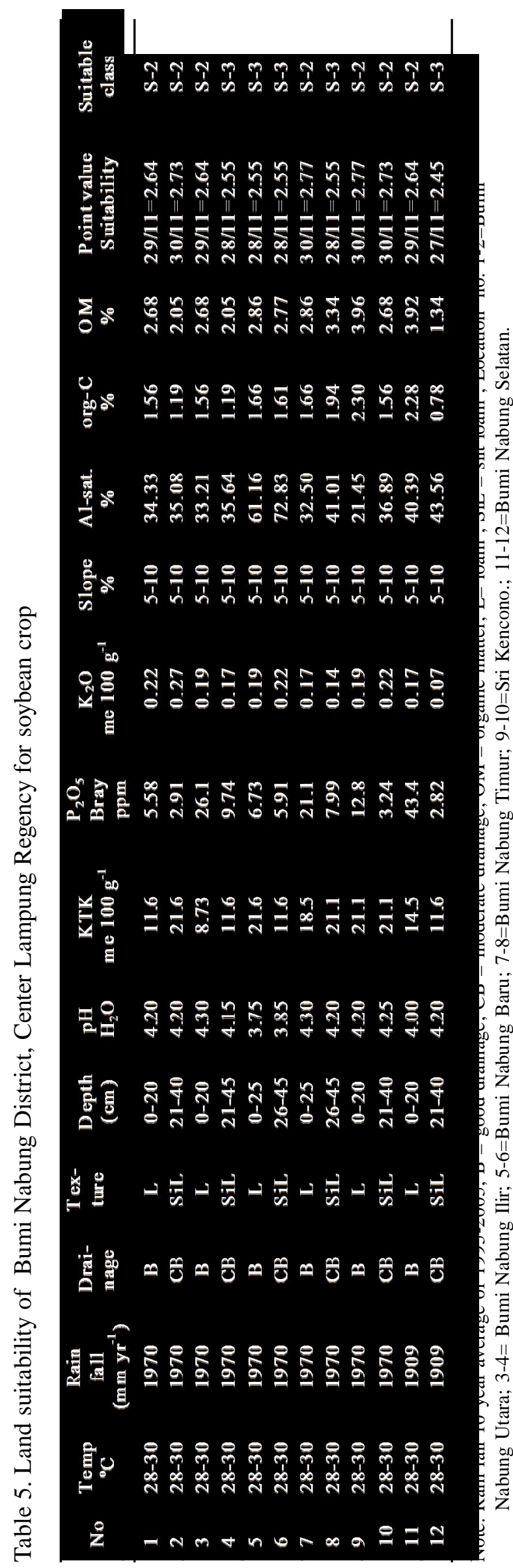

of the standard technology components to reduce the $\mathrm{Al}$ and $\mathrm{Fe}$ activity in acid dry land. The use of agricultural lime in the form of $\mathrm{CaCO}_{3}$ and Dolomite and organic material to improve land productivity has long been recommended and done (Kamprath 1972; Mengel et al. 1987). Liming can be effective if the saturation acidity $(\mathrm{Al}+\mathrm{H})>10 \%$ and soil $\mathrm{pH}<5$ (Wade et al. 1986).

Practical actions suggested are (1) improving soil physical fertility through land preparation to achieve sufficient condition of soil solum (40-50 $\mathrm{cm})$, loosing soil structure, increasing moisture holding capacity, (2) improving the fertility of soil chemistry through amelioration (zeolite, dolomite, lime, ameliorant organic), organic fertilization and inorganic (NPK, and certain micro-nutrient), (3) repairing of biological fertility with fertilizers containing biological soil microbes, especially phosphate solubilizing microorganism, vesicular arbuscular mycorrhiza, and non-symbiotic $\mathrm{N}$-fixing bacterial, and (4 ) settings cropping pattern or rotation cropping are more productive.

\section{CONCLUSIONS}

Agricultural land in the districts of Bumi Nabung and Rumbia had a low fertility soil to grow soybean plants. Development of soybean production in these two districts should be supported by technology components such as soybean cultivation, utilization of soil ameliorant (dolomite, agricultural lime, zeolite), fertilization with organic fertilizers (compost, manure) and inorganic fertilizer (NPK).

Most agricultural land in these two districts have the suitable (appropriate) for soybean (S-2) and a small percentage of less suitable (S-3). Increased suitability classes from S-3 to S-2 and even $\mathrm{S}-1$ might be made possible by manipulation of the physical and chemical characteristics of soil with addition of soil ameliorant zeolite, dolomite or ameliorant organic, as well as organic and inorganic fertilizations.

\section{REFERENCES}

Abdurachman A, K Nugroho and AS Karama. 1998. Optimalisasi pemanfaatan sumberdaya lahan untuk mendukung program Gema Palagung. In: Sudaryono et al. (eds) 1998. Prosiding Seminar Nasional dan Pertemuan Tahunan Komisariat Daerah Himpunan Ilmu Tanah Indonesia Tahun 1998, pp. 1-11 (in Indonesian).

BPTP [Balai Pengkajian dan Teknologi Pertanian] . 2005a. Program Penyuluh Pertanian Tanaman Pangan dan Hortikultura. Kecamatan Bumi 
费

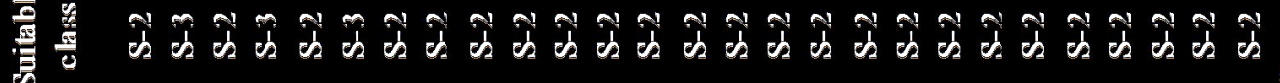
ए人

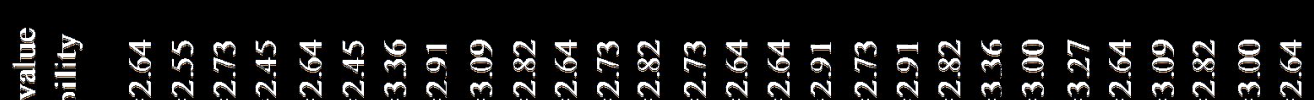

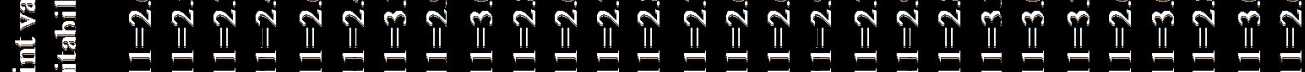

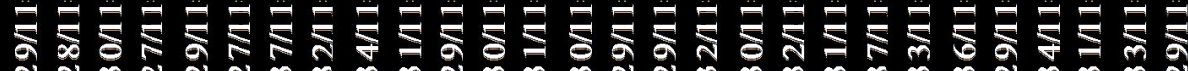

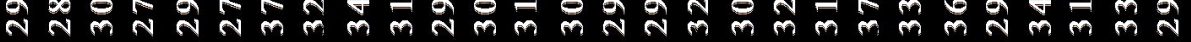

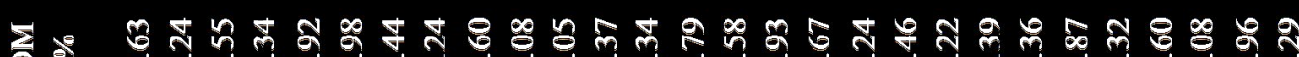

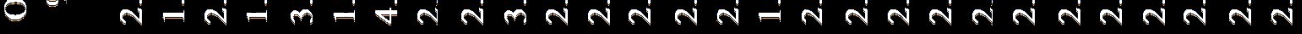

บํํㅇำ

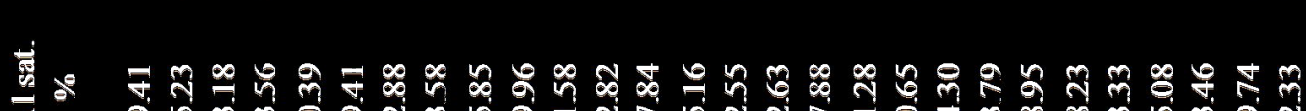

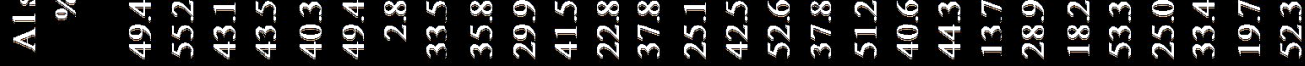

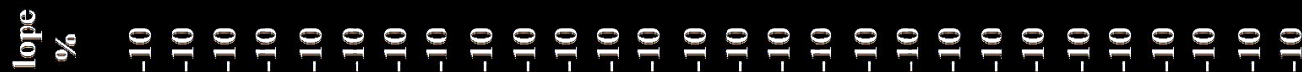

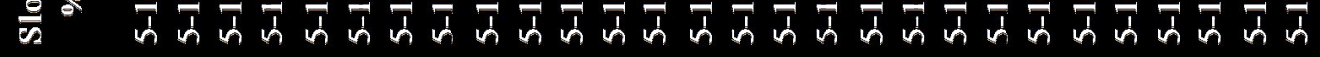

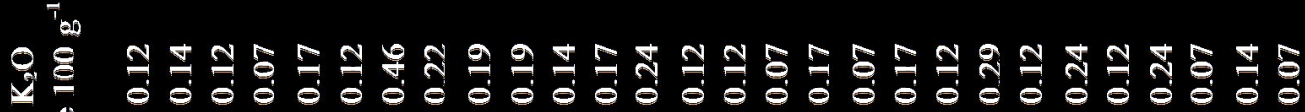

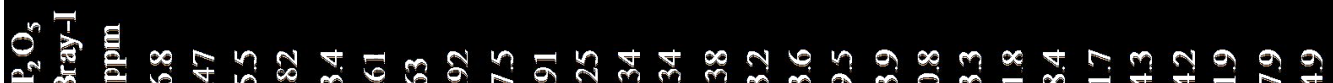

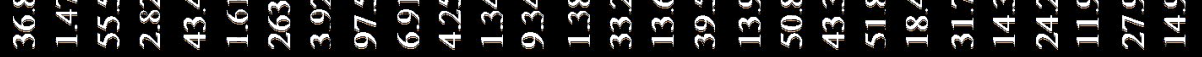
를

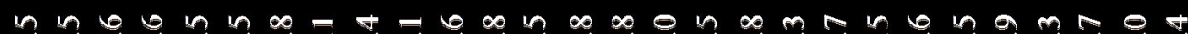

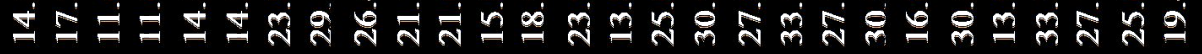

플

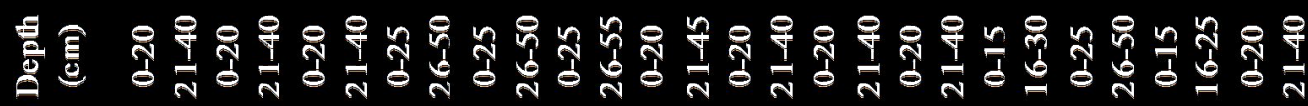

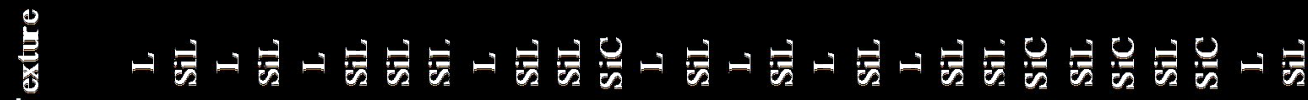

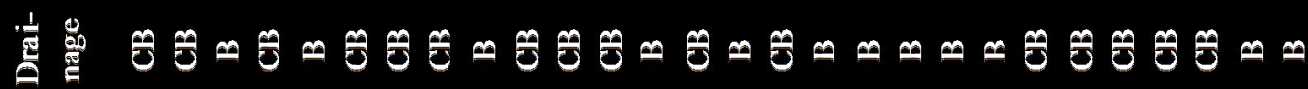
焉 恶

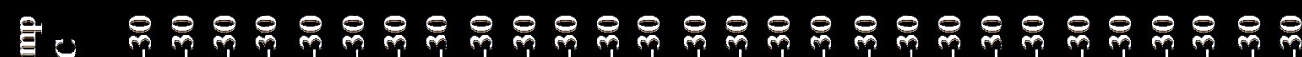

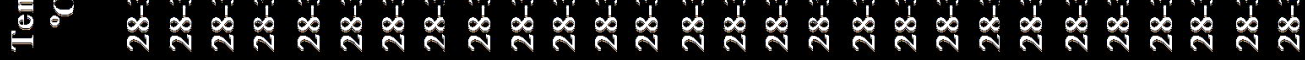
是 은ำ 
Nabung. Kabupaten Lampung Tengah, 27 p (in Indonesian).

BPTP [Balai Pengkajian dan Teknologi Pertanian]. 2005b. Program Penyuluh Pertanian Tanaman Pangan dan Hortikultura. Kecamatan Rumbia. Kabupaten Lampung Tengah, 30 p (in Indonesian).

Baharsjah YS, D Suardi and I Las. 1985. Hubungan Iklim dengan Pertumbuhan Kedelai. In: S Somaatmadja et al. (eds). Kedelai. Badan Litbang Pertanian, Puslitbangtan. Bogor, 87-102 (in Indonesian).

BPS [Badan Pusat Statistik]. 2004. Lampung Tengah dalam Angka. Badan Pusat Statistik Kabupaten Lampung Tengah. 259 p.

CSR-FAO [Centre for Soil Research-Food Agriculture Organization]. 1983. Reconnaissance land resource surveys $1: 250,000$ scale. Atlas Format Procedures. AGOF/INS/78/006. Manual 4. Version 1.

Kamprath EJ. 1972. Exchangeable Al as a criterion for liming leached mineral soil. Soil Sci Am Proc 34: 252-254.

Halliday DJ and ME Trenkel. 1992. IFA World Fertilizer Use Manual. International Fertilizer Industry association (IFA). Paris.

Hartatik W and JS Adiningsih. 1987. Pengaruh pengapuran dan pupuk hijau terhadap hasil kedelai dan pada tanah Podsolik Sitiung di Rumah Kaca. Pemb Pen Tanah dan Pupuk 7: 1-4 (in Indonesian).

Landon JR. 1984. Booker Tropical Soil Manual. A Handbook for soil survey and agricultural land evaluation in the tropics and subtropics. BAI Limited. Bloomsbury House 74-77 Great Russell Street London WC18 3DF England.
Mengel DB, W Segars and GW Rehnm. 1987. Soil fertility and liming. In: J R Wilcox (ed). Soybean Improvement and Uses. Second Edision. ASDA. Madison, pp. 461-496.

Shibusawa S. 2002. Precision Farming Approaches to Small-Farm Agriculture. Food \& Fertilizer technology Center. Technical Bulletin 160,10 p.

Sudaryono. 1994. Rencana Pembangunan Wilayah (RPW) Kecamatan Solokuro Lamongan. In: MM Dahlan et al. (eds). Risalah Seminar Hasil Penelitian Tanaman Pangan di Tanah Mediteran (Alfisol). Balai Penelitian Tanaman Pangan Malang. Edisi Khusus Balittan Malang No. 4. 1994, pp. 104-128 (in Indonesian).

Taufiq A, H Kuntyastuti and AG Manshuri. 2004. Pemupukan dan ameliorasi lahan kering masam untuk peningkatan produktivitas kedelai. Makalah Lokakarya Pengembangan Kedelai Melalui Pendekatan Pengelolaan Tanaman Terpadu di Lahan Masam. BPTP Lampung, pp. 21-40 (in Indonesian).

Truog E. 1973. Mineral Nutrition of Plants. Publish by Mohan Primlani, Oxford \& IBH Publishing Co. 66 Janpath. New Delhi. 469 p.

Wade MK, M Al-Jabri and M Sudjadi. 1986. The effect of liming on soybean yield and soil acidity parameters of three Red-Yellow Podsolic soils of west Sumatera. Pemb Pen. Tanah dan Pupuk 6: 18.

Widjaja-Adhi IPG. 1985. Pengapuran tanah masam untuk kedelai. Hal.: 171-188. In: S Somaatmadja et al. (eds). Kedelai. Badan Litbang Pertanian, Puslitbangtan. Bogor. 